NOTE

\title{
Settlement of Chlamys tehuelchus (D'Orb.) on artificial collectors. Seasonal changes in spat settlement*
}

\author{
Daniel E. Ruzzante** \& Héctor E. Zaixso \\ Centro Nacional Patagónico (CONICET), 28 de julio 28, 9120 Puerto Madryn, Chubut, Argentina
}

\begin{abstract}
Seasonal changes in the settlement of the pectinid Chlamys tehuelchus (D'Orb.) were studied at a site in the San José Gulf (Chubut, Argentina). Two discontinuous series of experiments were carried out during 1978 to 1980 and 1980 to 1982 by setting out artificial collectors made of plastic mesh bags ( $1.5 \mathrm{~mm}$ mesh) filled with standardized quantities of 'tangle' of polyethylene monofilament. Results suggest that the main spat collection of Chlamys tehuelchus takes place between November and April with a peak generally in February.
\end{abstract}

For the past 10 yr scallop fisheries have had a great importance in the economy of the San Matías and San José Gulf areas. They have depended entirely on natural stocks which, however, had almost died out due to overfishing in the San Matías Gulf (Olivier et al. 1974, Zaixso 1980a). Artificial spat collection may have great potential value in maintaining production.

The techniques used in the present work were in general taken from Japanese cultivation systems for Patinoepcten yessoensis (Jay) (Ventilla 1982). The study of monthly variation in spat settlement of Chlamys tehuelchus on artificial collectors and the determination of peaks are of the utmost importance in developing commercial culture techniques for this species (Brand et al. 1980, Zaixso 1980b, Paul et al. 1981, Ventilla 1982). Collectors placed in the sea too long before the expected settlement of $C$. tehuelchus are susceptible to collecting any other species, which might compete with the scallop (Naidu \& Scaplen 1976), or simply reduce water flow through the mesh (Brand et al. 1980, Zaixso \& Espindola 1981). On the other hand, collectors placed after the expected time do not collect maximum quantities of spat. During recent years several studies on the settlement period of different pectinids have been carried out, especially for species from the northern hemisphere (MullerFeuga \& Querellou 1973, Naidu \& Scaplen 1976, Pick-

- Contribution of the Centro Nacional Patagónico

- Present address: Biology Department, Dalhousie University, Halifax, Nova Scotia B3H 4J1, Canada ett 1977, Brand et al. 1980, Burnell \& Rodhouse 1980, Slater 1980, Paul et al. 1981, Ventilla 1982, Wallace 1982). The following account gives information on seasonal changes in $C$. tehuelchus (D'Orb.) spat settlement.

Two series of experiments were performed in San José Gulf (Chubut, Argentina) near a commercially important scallop area. The first series was carried out between November 1978 and February 1980 and the second series between November 1980 and April 1982.

The collectors were made from plastic mesh bags (50 $\times 40 \mathrm{~cm}$ with $1.5 \mathrm{~mm}$ mesh) and were filled with standardized quantities of teased polyethylene monofilament ( $40 \mathrm{~g}$ in the first series and $50 \mathrm{~g}$ in the second). Two ropes, each having 3 collector bags, were placed in the sea, with a weight at one end and a subsurface buoy at the other. The bags were fixed on the rope at $2 \mathrm{~m}$ intervals, so that they remained 2 to $6 \mathrm{~m}$ from the bottom. Ropes and bags were replaced at 1 mo intervals. Depth was $10 \mathrm{~m}$ at low tide and $16 \mathrm{~m}$ at high tide.

The monthly collector bags were washed vigorously in a bucket. Then the scallops collected were sieved through a $250 \mu \mathrm{m}$ mesh and counted under a stereomicroscope. In the first series, individuals were also measured. During the first series, 96 collector bags were analyzed and 108 during the second. Actual settlement values of the first and second series are not directly comparable because of the differences in the quantity of polyethylene monofilament tangle, which affected the spat settlement number (Zaixso \& Espíndola 1981).

All data were first transformed into natural logarithm (ln $[X+1])$. Then, after having assessed the homogeneity of variances, an analysis of variance was performed.

First series (Nov 1978 to Feb 1980). An analysis of variance was performed with the monthly settlement values, excluding those of May to October, in which settlement was nil, or (August) collectors were lost at sea (Fig. 1). In this series, size and size range of the 


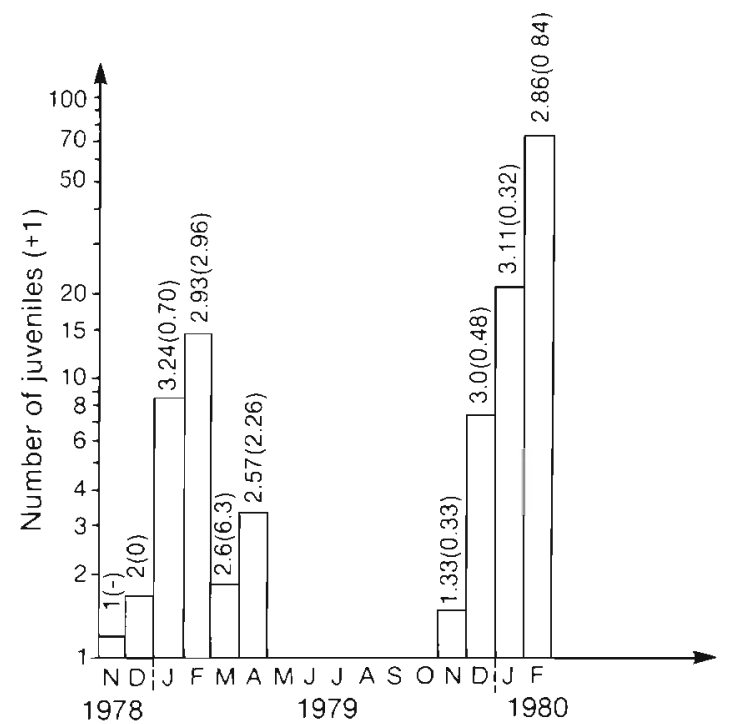

Fig. 1. Chlamys tehuelchus. First series settlement values. Monthly spat mean sizes and (variance) are shown above each bar

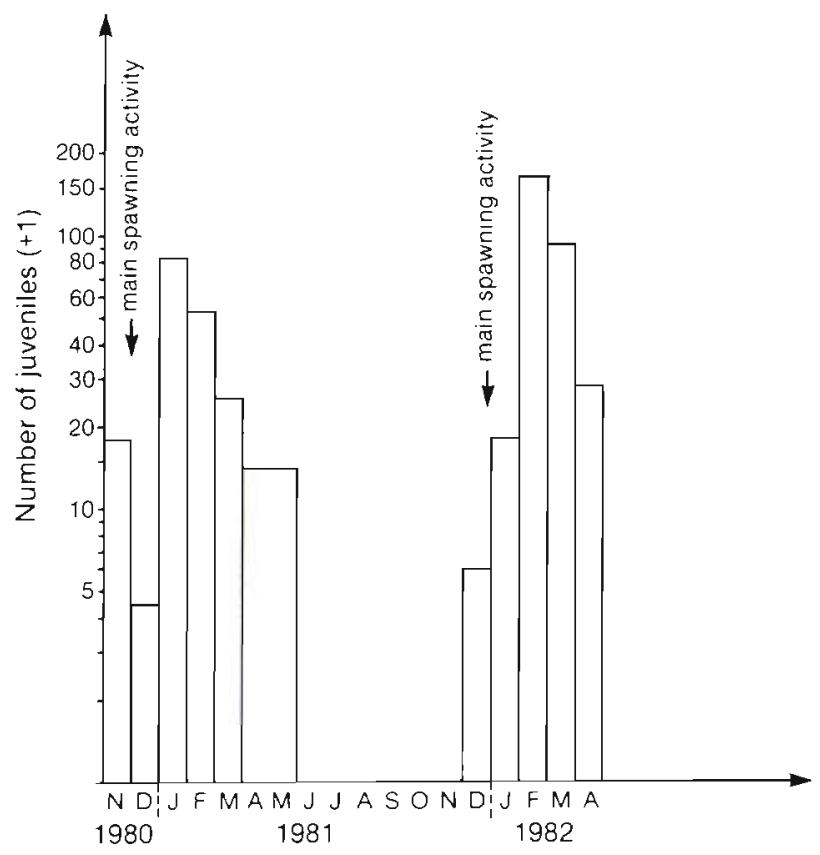

Fig. 2. Chlamys tehuelchus. Second series settlement values

spat was also measured; the average size per month and the variance are shown in Fig. 1

Highly significant differences were found between the monthly settlement values $(F=22.488$; d.f. $=9$ / 50; $\mathrm{p}<0.01$ ). The months with the highest spat quantities were January, February, December 1979, and January, February 1980 (Fig. 1).

Second series (Nov 1980 to Apr 1982). As before an analysis of variance was performed. Months without spatfall were not taken into account (June to
November 1981). In some cases, collector bags were lost. The collectors placed at sea in April 1981 remained there for almost 2 mo due to bad weather conditions (Fig. 2).

Highly significant differences were again found between the monthly settlement values $(F=23.715$; d.f. $=10 / 41 ; p<0.01$ ). The months with the highest spat settlement mean values were: January, February 1981, and February, March 1982 (Fig. 2).

It can be concluded that the time of spat settlement of Chlamys tehuelchus on artificial collectors in the San José Gulf lasts from November through April with a peak generally in February.

Ciocco (unpubl.), who studied the sexual cycle of this species through histological observations for the period 1980 to 1982 , concluded that mass spawning took place mainly in December during the summer season 1980 to 1981 and in December to January during the summer season 1981 to 1982.

Spats whose size varied between 1 and $3 \mathrm{~mm}$ were found in bottom samples taken at the beginning of January 1982 (Ciocco pers. comm.). It can be assumed then that the spatfall occurred 2 or 3 wk before, that is to say in December 1981. These results are similar to those obtained in a previous study by Lasta \& Calvo (1978). It can be seen that in both summer seasons (1980-1981 and 1981-1982) mass spawning activity took place roughly 1 mo before the peak of spatfall (Fig. 2) and can therefore be used as a predictor for the time of placing collectors at sea.

The exact timing of the peak may differ from year to year, as it depends mainly on climatic or physical conditions, such as fluctuations of the annual seawater temperature cycles, salinity, and food availability (Bayne 1965, Thorson 1966, Sastry 1979), which affect not only the gonadal cycle in adults (Raimbault 1966) but also larval development (Bayne 1965, Calabrese 1969, Bourne \& Smith 1972, Widdows 1978, Sastry 1979 [p. 202], Newell \& Bayne 1980).

Isolated Chlamys tehuelchus spats have been found in the sea bottom in winter (Ciocco pers. comm.). During this period (May to early November) no settlement occurred on artificial collectors. A similar case was reported for $C$. opercularis in the northern Irish Sea (Brand et al. 1980). These authors affirm that natural settlement of the species takes place throughout the year on benthic epifauna, while no spats are to be found on collectors placed at sea after September.

It was found in a previous study on the San José Gulf area (Zaixso \& Toyos in press) that although different spat quantities were counted at different depths, the depth distribution was not always the same. This lack of an optimal value in the depth distribution may be due to the variable conditions of the water mass, i.e. shallow depth and high tidal range. 
The present study demonstrates the strong seasonality in spat settlement of Chlamys tehuelchus (D'Orb.) and the high potential value that artificial collection methods can have in developing the scallop fisheries in this area.

Acknowledgements. We thank Mc. M. A. Diaz and Mr. A. Sosa for assistance in the field, and 2 anonymous reviewers and also Dr. Gary Newkirk for their assistance in improving the original manuscript

\section{LITERATURE CITED}

Bayne, B. L. (1965). Growth and the delay of metamorphosis of the larvae of Mytilus edulis (L.). Ophelia 2 (1): 1-47

Bourne, N., Smith, D. W. (1972). The effect of temperature on the larval development of the horse clam, Tresus capax (Gould). Proc. natn. Shellfish Ass. 62: 35-37

Brand, A. R., Paul, J. D., Hoogesteger, J. N. (1980). Spat of the scallops Chlamys opercularis (L.) and Pecten maximus (L.) on artificial collectors. J. mar. biol. Ass. U. K. 60: 379-390

Burnell, G. M., Rodhouse, P. G. (1980). Growth and reproduction of the variegated scallop. Chlamys varia (L.). 3rd Scallop Workshop. Port Erin, Isle of Man, 13-16th May, 1980

Calabrese, A. (1969). Individual and combined effects of salinity and temperature on embryos and larvae of the coot clam Mulinia lateralis (Say). Biol. Bull. mar. biol. Lab., Woods Hole 137 (3): 417-428

Lasta, M. L., Calvo, J. (1978). Ciclo reproductivo de la vieira (Chlamys tehuelcha) del golfo San José. Comunicaciones de la Soc. Malac. Urug. V (35): 1-43

Muller-Feuga, A., Querellou, J. (1973). L'exploitation de la coquille Saint-Jacques au Japon. Rapp. Scient. Techn., CNEXO, No. 14, p. $1-85$

Naidu, K. S., Scaplen, R. (1976). Settlement and survival of giant scallop, Placopecten magellanicus, larvae on enclosed polyethylene film collectors. In: Pillay, T. V. R., Dill, Wm. A. (ed.) Advances in aquaculture. FAO Technical Conference on Aquaculture, Kyoto, Japan, 26 May2 June 1976. Fishing News Books Ltd., Farnham

Newell, R. I. E., Bayne, B. L. (1980). Seasonal changes in the physiology, reproductive condition and carbohydrate content of the cockle Cardium (= Cerastoderma) edule (Bivalvia: Cardiidae). Mar. Biol. 56: 11-19

Olivier, S. R., Orensanz, J. M., Capitoli, R., Quesada-Allue, L. A. (1974). Estado actual de las poblaciones de Vieira,
Chlamys tehuelcha en las costas Norte y Sur del golfo San José, provincia del Chubut. Serie Informes Científicos del Centro Nacional Patagónico, No. 2, p. 1-20

Paul, J. D., Brand, A. R., Hoogesteger, J. N. (1981). Experimental cultivation of the scallops Chlamys opercularis (L.) and Pecten maximus (L.) using naturally produced spat. Aquaculture $24: 31-44$

Pickett, G. D. (1977). Artificial collection of pectinid spat: preliminary experiments in Start Bay, South-West England, 1975-1977. Coun. Meet. int. Counc. Explor. Sea. Fisheries Improvement Committee. C.M.-ICES/E:49

Raimbault, R. (1966). Reproduction et stades planctoniques des mollusques. Rev. Trav. Inst. Pêches maritimes 30 (2): 251-265

Sastry, A. N. (1979). Pelecypoda (excluding Ostreidae). In: Giese, A. C., Pearse, J. S. (ed.) Reproduction of marine invertebrates, Vol. V (Molluscs: Pelecypods and lesser classes), Chap. 5. Academic Press, New York, p. 113-292

Slater, J. (1980). Prediction of the time of peak settlement of the scallop, Pecten maximus by pectinid larval monitoring. 3rd Scallop Workshop, Port Erin, Isle of Man. 13-16th May, 1980

Thorson, G. (1966). Some factors influencing the recruitment and establishment of marine benthic communities. Neth. J. Sea Res. 3 (2) : 267-293

Ventilla, R. F. (1982). The scallop industry in Japan. Adv. mar. Biol. 20: 309-382

Wallace, J. C. (1982). The culture of the Iceland scallop, Chlamys islandica (O. F. Müller). I. Spat collection and growth during the first year. Aquaculture 26: $311-320$

Widdows, J. (1978). Combined effects of body size, food concentration and season on the physiology of Mytilus edulis. J. mar. biol. Ass. U. K. 58: 109-124

Zaixso, H. E. (1980a). Moluscos argentinos de interés comercial y sus posibilidades de cultivo. Contr. No. 22 del Centro Nacional Patagónico

Zaixso, H. E. (1980b). Captación de Chlamys tehuelchus (D'Orb.) sobre colectores. Observaciones preliminares. Contr. No. 37 del Centro Nacional Patagónico, p. 1-20

Zaixso, H. E. de Espindola, J. A. (1981). Captación de Chlamys tehuelchus sobre colectores. II. Cantidad de material colector. Contr. No. 50 del Centro Nacional Patagónico, p. 1-11

Zaixso, H. E., Toyos, A. (1982). Captación de Chlamys tehuelchus (D'Orb.) sobre colectores. III. Observaciones sobre el nivel de colocación. Contr. No. 58 del Centro Nacional Patagónico

Accepted for printing on June 18, 1985 